\title{
Geociênchcias
}

\section{The rheology of banded iron formation: constraints from axial compression experiments}

\section{A reologia de formação ferrífera bandada: estudo a partir de experimentos de compressão axial}

Cristiane Castro Gonçalves

DEGEO-EM-UFOP.

cristiane@degeo.ufop.br

\section{Greg Hirth}

Department of Geological Sciences,

Brown University, USA.

greg hirth@brown.edu

Leonardo Lagoeiro

DEGEO-EM-UFOP.

lagoeiro@degeo.ufop.br

\section{Resumo}

Amostras de formações ferríferas bandadas (BIF), compostas por diferentes proporções de quartzo e hematita foram deformadas, em experimentos de compressão axial, usando-se a prensa triaxial de Griggs, sob $\mathrm{T}=900^{\circ} \mathrm{C}, \mathrm{P}=1.5 \mathrm{GPa}$ e taxas de deformação de $10^{-5}$ e $10^{-6} \mathrm{~s}^{-1}$. O principal objetivo é investigar qual fase mineral controla a reologia de rochas poliminerálicas e determinar os processos que controlam a resistência observada para tais rochas. Amostras de BIF, da região do Quadrilátero Ferrífero, foram cortadas perpendicularmente à foliação, que é definida por bandas paralelas de quartzo e óxidos de ferro. A resistência das amostras diminui com o aumento da porcentagem de hematita e com a diminuição da taxa de deformação. Sob taxa de deformação de $10^{-5} \mathrm{~s}^{-1}$, amostras com bandamento composicional bem desenvolvido mostraram a mais alta resistência. Sob taxa de deformação mais lenta, $10^{-6} \mathrm{~s}^{-1}$, significativa diferença entre amostras com ou sem bandamento composicional não é observada. Como comparação, a $10^{-6} \mathrm{~s}^{-1}$, a amostra com a mais alta porcentagem de quartzo é tão fraca quanto a amostra com a mais alta porcentagem de hematita a $10^{-5} \mathrm{~s}^{-1}$. A deformação é localizada nas bandas ricas em hematita e uma observação intrigante é que os grãos de quartzo, nessas bandas, mostram maior evidência de deformação cristal-plástica que os grãos presentes em bandas quartzosas.

Palavras-chave: Formação ferrífera bandada, reologia, deformação experimental, compressão axial.

\begin{abstract}
Samples of Banded Iron Formation (BIF) with different quartz and hematite contents were deformed in axial compression experiments in a Griggs-type apparatus, at $T=900^{\circ} \mathrm{C}, P=1.5 \mathrm{GPa}$ and strain rates of $10^{-5}$ and $10^{-6} \mathrm{~s}^{-1}$. The aim is to investigate the mineral phase that controls the rheology of multi-phase rocks and to determine the processes that control the observed rock strength. BIF samples from Quadrilatero Ferrifero region-Brazil were cored perpendicular to the foliation, which is defined by parallel bands of quartz and iron oxide. Sample strength decreases with increasing hematite content and decreasing strain rate. At a strain rate of $10^{-5} \mathrm{~s}^{-1}$, samples with well-developed compositional banding showed higher strength. At the slower strain rate of $10^{-6} \mathrm{~s}^{-1}$ no difference between samples with or without compositional banding is observed. For comparison, at $10^{-6} \mathrm{~s}^{-1}$, the highest quartz content sample is as weak as the highest hematite content sample at $10^{-5} \mathrm{~s}^{-1}$. Strain is localized in hematite-rich layers. One intriguing observation is that quartz grains within the more deformed hematite-rich bands show more evidence for crystal-plastic deformation than grains in quartz-rich bands.
\end{abstract}

Keywords: Banded iron formation, rheology, experimental deformation, axial compression. 


\section{Introduction}

One of the biggest challenges in studying the dynamics of the Earth is to understand how rocks deform. As discussed by Bürgmann \& Dresen (2008), knowledge about the kinematics of lithospheric plates is insufficient to understand phenomena such as the mechanical interaction between the lithosphere and asthenospheric mantle or why deformation localizes at the boundaries of lithospheric plates. Numerous studies have been conducted to analyze macro and microstructures, textural patterns and field stresses related to them, mechanisms of ductile flow in mineral aggregates and mechanical properties relating strain and applied stress through constitutive equations (e.g. Gleason \& Tullis, 1993, Gleason \& Tullis, 1995, Hirth \& Kohlstedt, 1995a,b, Karato et al., 1986, Post \& Tullis, 1999, Mei \& Kohlstedt, 2000 a,b, Stunitz \& Tullis, 2001, Stunitz et al. 2003, Hirth et al., 2001, Hansen et al., 2011). Based on natural and mainly experimental observations, rheological properties of quartz, quartzo-

\section{Starting material}

Samples of BIF were collected in the northeast region of Quadrilátero Ferrífero area and are comprised of quartz and specular hematite, distributed in layers with different proportions of these phases. Two types of samples were deformed: (i) samples with welldeveloped compositional banding, showing nominally pure quartz bands (quartz content: 90\% of its bulk com-

\section{Experimental procedure}

Samples were deformed using a Griggs-type apparatus (Tullis \& Tullis, 1986), at $900^{\circ} \mathrm{C}$ and a confining pressure of $1.5 \pm 0.1 \mathrm{GPa}$, at constant displacement rates of $1.83 \times 10^{-4} \mathrm{~mm} / \mathrm{s}$ and $1.83 \times 10^{-5}$ $\mathrm{mm} / \mathrm{s}$, corresponding to constant strain rates of $1.5 \times 10^{-5} / \mathrm{s}$ and $1.5 \times 10^{-6} / \mathrm{s}$, respectively (Table 1). Samples were first cored perpendicular to compositional banding/ foliation, then cut and polished in order to produce flat and parallel end surfaces to produce cylindrical samples $12.7 \mathrm{~mm}$ long and $6 \mathrm{~mm}$ in diameter (Figure 1C). Axial compression experiments, with $\sigma_{1}>\sigma_{2}=$ $\sigma_{3}$, were performed to an axial strain of $40 \%$. The axial stress $\left(\sigma_{1}\right)$ is transmitted to the sample inside of a furnace by opposing pistons positioned at its ends, which are feldspathic and olivine rich aggregates have been determined and models about the strength of the lithosphere have been established (e.g. Goetze \& Evans, 1979, Brace \& Kohlstedt, 1980, Brudy et al., 1997, Jackson, 2002, Hirth \& Kohlstedt, 2003, Rutter \& Brodie, 2004a,b, Burov \& Watts, 2006). Nevertheless, most of these studies make use of monophasic aggregates and the rheology of polyphase aggregates is poorly understood, although in nature mineral aggregates are generally composed of phases with highly contrasting strength, commonly quartz, phyllosilicates and felsdspars, or similarly quartz and iron oxides.

High temperature creep experiments on quartz rich aggregates have been conducted since the 1960's, and the strength of nominally pure quartz aggregates is well characterized: as natural or synthetic aggregates; in the presence of water or under dry condition; under different levels of oxygen and water fugacity; varying temperature, confining

position) with lenticular morphology bounded by domains with fine microlayering of quartz and hematite (Figure 1A) (samples W1533 and W1556); (ii) samples with high quartz content $(\sim 75 \%$ of bulk composition) but in which the quartz is more dispersed among specular hematite crystals oriented parallel to the compositional banding (Figure 1B) (samples W1530 and W1565). The

compressed by a load piston driven by a motor at constant rate (Figure 1C). The confining pressure $\left(\sigma_{3}\right)$ is applied to the sides of the sample through a very weak solid $(\mathrm{NaCl}$, in this case, Figure $1 \mathrm{C})$, which is applied by compression of the confining pressure piston using hydraulic ram connected to a hand pump.

Displacement of both the loading and confining pressure pistons is measured by a direct current differential transformer, DCDT. Force is measured on an external load cell for the load piston, and with a pressure transducer that measures the hydraulic oil pressure for the confining pressure piston.

The sample strain is determined using the load piston displacement by divid- pressure and strain rates (e.g. Tullis et al., 1973, Twiss, 1977, Kronenberg \& Tullis, 1984, Mainprice \& Paterson, 1984, Dell'Angelo \& Tullis, 1989, Hirth \& Tullis, 1992, Post \& Tullis, 1998, Rutter $\&$ Brodie, 2004a,b, Stipp et al., 2006, Chernak et al., 2009). The rheology of iron oxides has not been deeply studied, but studies on pure hematite aggregates indicate they are much weaker than quartz aggregates (Siemes et al., 2003, Siemes et al., 2008, Siemes et al., 2010). The rheology of rocks made up of quartz and iron oxides has not been studied yet, although their microfabric and deformation history are intimately related to the deformation history of ore deposits, such as in the Quadrilátero Ferrífero region, Minas Gerais - Brazil (e.g. Rosière et al., 2001 and 2008). From these perspectives, Banded Iron Formation (BIF) samples, comprised of quartz and hematite grains, were chosen to conduct a set of axial compression experiments under high temperature and pressure. main difference between the two types of samples is the size of quartz grains: the first sample shows an average size between 170 and $200 \mu \mathrm{m}$ within the quartz bands; the quartz grains in the second sample are less than $\sim 50 \mu \mathrm{m}$. The foliation in both samples is defined by hematite platelets with a strong shape preferred orientation, parallel to the compositional banding. ing the sample displacement by the initial sample length. Elastic distortion of the load system must be subtracted from the load piston displacement. The temperature is controlled by the electrical power to the furnace and is measured using a thermocouple placed next to the sample (Figure 1C). The furnace is a graphite tube, surrounded by tubes of pyrophyllite that serve as insulators (Figure 1C).

Experimental conditions were chosen so that dislocation creep regimes for quartz grains were attained (Hirth \& Tullis, 1992). The procedure was the same as used by Kronenberg \& Tullis (1984) and Post \& Tullis (1998): temperature and pressure were raised stepwise, increasing temperature and 
Figure 1

Samples of banded iron formation: (A) well developed compositional bands, showing pure quartz bands limited by "wavy" foliation and also domains with fine micro-layering. (B) weak banding, but pervasive foliation defined by well-oriented specular hematite grains (black).

(C) Schematic drawing showing the sample assembly used for cylindrical samples, $12.7 \mathrm{~mm}$ long.

Table 1

Experimental details. Values are for: $\mathrm{T}$, temperature; $\mathrm{P}_{c}$, confining pressure; original sample length; strain rate; total axial strain; time at temperature and confining pressure. Iron oxides are not differentiated because do not imply rheological differences (Siemes et al., 2003).

pressure at rates of $30^{\circ} \mathrm{C} / \mathrm{min}$ and 25 $\mathrm{MPa}$ respectively each 5 minutes. Initially we increase temperature to $100^{\circ} \mathrm{C}$ at $250 \mathrm{MPa}$, to $200^{\circ} \mathrm{C}$ at $400 \mathrm{MPa}$, to $300^{\circ} \mathrm{C}$ at $600 \mathrm{MPa}$; then pressure was raised at a rate of $100 \mathrm{MPa}$ each $15 \mathrm{~min}$ -

\section{Results}

\section{Mechanical Data}

The sample with better defined compositional banding (strong anisotropy) and higher quartz content has the highest peak of stress at $10^{-5} \mathrm{~s}^{-1}, 325 \mathrm{MPa}$, achieved at axial strain $(\varepsilon)$ of $15 \%$; this sample then strain weakens to a steady state flow stress of $\sim 270 \mathrm{MPa}(\varepsilon=35 \%$, Figure 2A - W1533). The more homog-

。
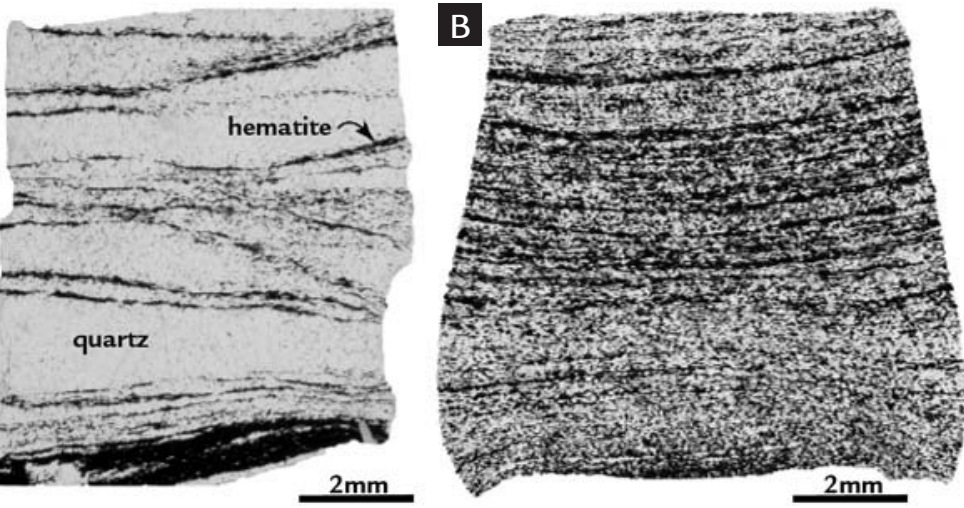

C.
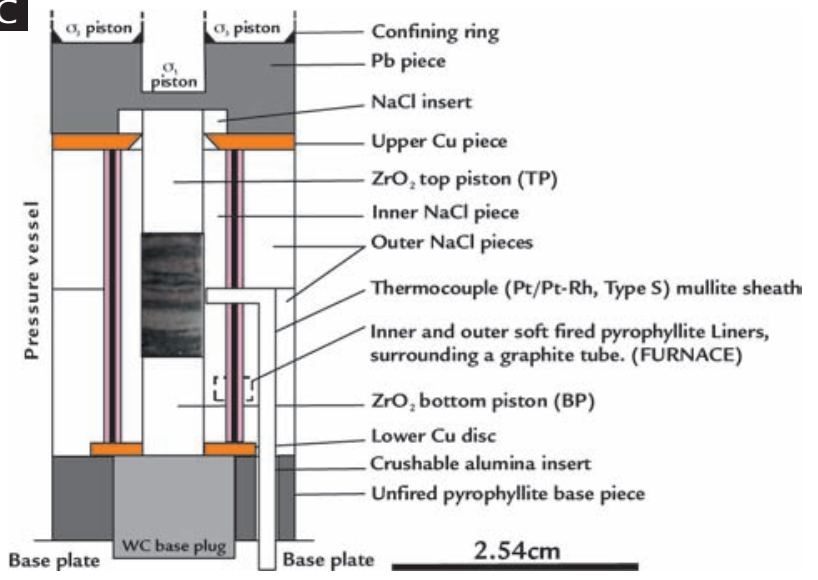

\begin{tabular}{c|c|c|c|c|c|c|c}
\hline Experiment & $\begin{array}{c}\mathbf{T} \\
\left({ }^{\circ} \mathbf{C}\right)\end{array}$ & $\begin{array}{c}\mathbf{P}_{\mathbf{c}} \\
(\mathbf{G P a})\end{array}$ & $\begin{array}{c}\text { Sample length } \\
(\mathbf{m m})\end{array}$ & $\begin{array}{c}\text { Strain rate } \\
\left(\mathbf{s}^{-1}\right)\end{array}$ & $\begin{array}{c}\varepsilon_{\text {flat }} \\
(\mathbf{\%})\end{array}$ & $\begin{array}{c}\mathbf{t}(\mathbf{h}) \text { at } \mathbf{P} \\
\text { and } \mathbf{T}^{*}\end{array}$ & $\begin{array}{c}\text { Iron oxide } \\
(\mathbf{\%})\end{array}$ \\
\hline $\mathrm{W} 1530$ & 900 & 1.5 & 12.08 & $1.5 \times 10^{-5}$ & 39 & 9.37 & $\sim 20$ \\
\hline $\mathrm{W} 1533$ & 900 & 1.5 & 12.95 & $1.5 \times 10^{-5}$ & 42 & 10.00 & $\sim 10$ \\
\hline $\mathrm{W} 1556$ & 900 & 1.5 & 12.36 & $1.5 \times 10^{-6}$ & 39 & 83.07 & $\sim 10$ \\
\hline $\mathrm{W} 1565$ & 900 & 1.5 & 12.65 & $\begin{array}{c}1.5 \times 10^{-6}, \\
\text { then } 1.5 \times 10^{-5}, \\
\text { then } 1.5 \times 10^{-6}\end{array}$ & 43 & 64.70 & $\sim 20$ \\
\hline $\mathrm{W} 1549$ & 900 & 1.5 & 12.02 & $\begin{array}{c}\text { Hydrostatic } \\
\text { experiment }\end{array}$ & --- & 10.00 & \\
\hline $\mathrm{W} 1551$ & 900 & 1.5 & 12.10 & $\begin{array}{c}\text { Hydrostatic } \\
\text { experiment }\end{array}$ & --- & 75.00 & \\
\hline
\end{tabular}

${ }^{*}$ Samples were held at $300^{\circ} \mathrm{C}$ and $1.3 \mathrm{GPa}$ prior deformation:

W1530/W1533/W1549/W1551 for 15h; W1556/W1565 for 4h.

utes, until 1.3 GPa. From this point we increased the temperature up to $900^{\circ} \mathrm{C}$ by increments of $100^{\circ} \mathrm{C}$. At the end of each experiment, samples were quenched under load to $300^{\circ} \mathrm{C}$, at a rate of $\sim 2^{\circ} \mathrm{C} / \mathrm{s}$, to preserve microstructures. Confining pressure and load were released slowly to minimize unloading cracks. Samples were recovered from the assembly and cut longitudinally; one half was then impregnated with epoxy and used to prepare doubly polished thin sections. enous sample with $\sim 25 \%$ of iron oxide is significantly weaker, showing a peak stress of $\sim 230 \mathrm{MPa}$ (W1565) at $10^{-5} \mathrm{~s}^{-1}$. At a strain rate of $10^{-6} \mathrm{~s}^{-1}$, there is little difference between the strength of the two types of samples (Figure 2A). At $10^{-6} \mathrm{~s}^{-1}$, the well-banded sample, with $\sim 90 \%$ of quartz shows a peak stress of $\sim 95 \mathrm{MPa}$ $(\varepsilon=10 \%)$, followed by strain weakening to $\sim 65 \mathrm{MPa}$ (W1556). In contrast, little or no strain weakening is observed in the more homogenous sample with lower quartz content (Figure 2A). The difference in strength between the two types of studied BIF is much lower at slower strain rate. At $10^{-5} \mathrm{~s}^{-1}$ the strength difference is 
between $100 \mathrm{MPa}$ (comparing W1533 and W1565) to $\sim 200 \mathrm{MPa}$ (comparing W1533 and W1530), while at $10^{-6} \mathrm{~s}^{-1}$ it is not more than $20 \mathrm{MPa}$. As $20 \mathrm{MPa}$ is close to the apparatus resolution (Holyoke and Kronenberg 2010), one can argue that there is no resolvable strength difference at $10^{-6} \mathrm{~s}^{-1}$ (Figure 2A - W1530, W1556 and W1565 - red line). The effect of strain rate on strength is well characterized by the strain rate stepping experiment on the type 2 sample (W1565); this experiment shows a flow stress of $\sim 110 \mathrm{MPa}$, at $10^{-6}$ $\mathrm{s}^{-1}$, a stress of $215 \mathrm{MPa}$ when strain rate is increased to $10^{-5} \mathrm{~s}^{-1}(\varepsilon=15 \%)$, and a stress of $\sim 65 \mathrm{MPa}$ when the strain rate is decreased back to $10^{-6} \mathrm{~s}^{-1}(\varepsilon=35 \%)$.

The strength of quartz and hematite aggregates at our deformation conditions are also shown in Figure 2; data for quartzite from Chernak et al. (2009) are shown in Figure 2A (dashed black line); data for hematite from Siemes et al. (2003) are shown in Figure 2B. The quartz aggregate deformed at the same condition $\left(900^{\circ} \mathrm{C}\right.$ and $\left.1.5 \mathrm{GPa}\right)$ is stronger, showing a peak stress of $485 \mathrm{MPa}$ and weakening to $\sim 325 \mathrm{MPa}(\varepsilon=\sim 45 \%)$. In contrast, pure hematite aggregates deformed at the same temperature but lower confining pressure shows a strength of $\sim 260 \mathrm{MPa}$ at $10^{-5} \mathrm{~s}^{-1}$, and $\sim 110 \mathrm{MPa}$ at $10^{-6} \mathrm{~s}^{-1}$, similar to our samples.

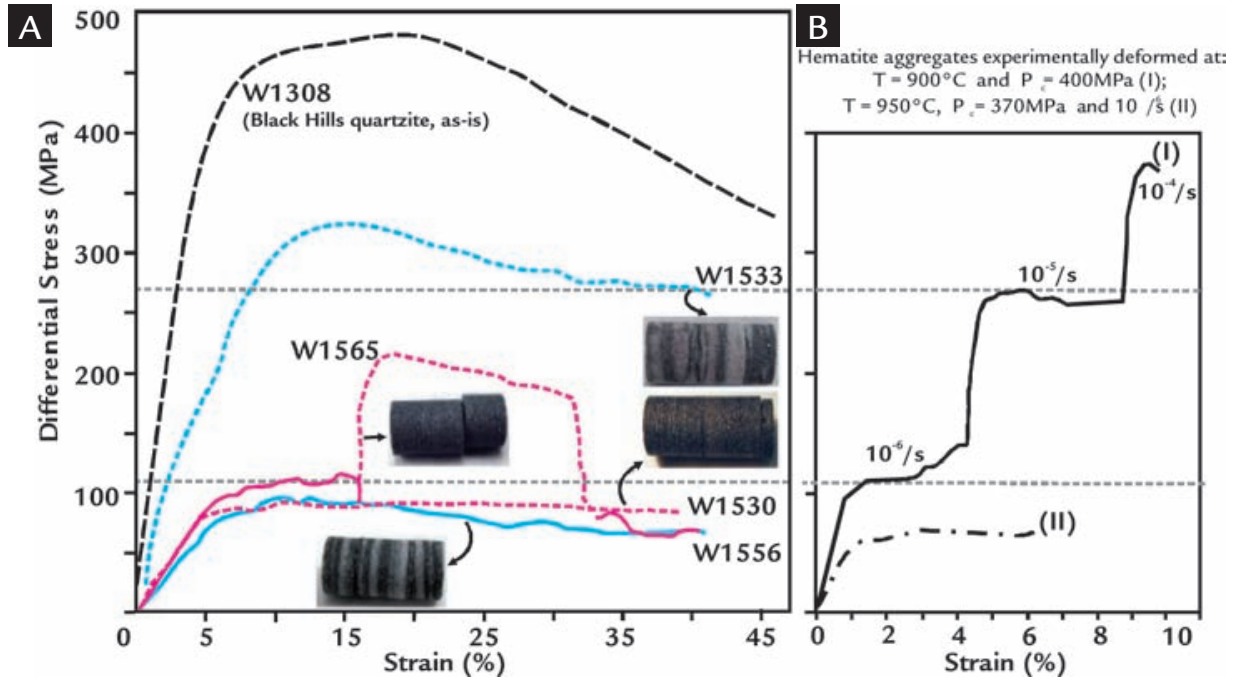

Figure 2

Differential stress versus axial strain plots.

A) Strength of studied BIF samples: dashed lines for experiments at $10^{-5} \mathrm{~s}^{-1}$ and solid lines for experiments at $10^{-6} \mathrm{~s}^{-1}$ (black dashed line from Chernak et al., 2009, blue curves for Type 1 and red curves for Type 2).

B) Strength of hematite aggregates presented by Siemes et al. (2003).

\section{Microstructures}

All samples show the development of a reaction rim resulting from the reduction of hematite to magnetite. The width of the rim increases for longer experiments (Figure 3A). In hydrostatically annealed samples (hydrostatic experiments, Table 1 ), magnetite is only observed in the reaction rim. In contrast, some randomly distributed magnetite grains are found in the center of deformed samples.

Samples with well-developed compositional banding show distinctive microstructures. At $10^{-5} \mathrm{~s}^{-1}$, quartz richer layers do not show recrystallized grains and only modest evidence for crystalplastic deformation (such as undulatory extinction and deformation lamellae)

\section{Discussion}

One of the biggest challenges in understanding the rheology of multiphase rocks is to understand the phase strength contrast (PSC). The magnitude of the PSC, together with the topology of the weak phase controls the degree of strain localization and weakening of multi-phase rocks (Handy, 1990, Stünitz \& FitzGerald, 1993, Stünitz \& Tullis, 2001, de Ronde et al., 2004 and 2005,
(Figure 3B). In contrast, within the hematite-rich bands, quartz grains surrounded by hematite flakes are flattened and show better defined deformation lamellae (Figure 3C). Magnetite grains, when present, form trails parallel to the compositional banding (Figure 3D). At slower strain rate quartz grains also show minor subgrain formation and sutured grain boundaries, surrounded by few very fine recrystallized grains (Figure $3 \mathrm{E})$, mainly present at the contact with iron oxide rich layers.

Deformation in the texturally homogenous samples, with higher iron oxide content is correspondingly more homogenous. Iron oxide grains form interconnected layers around quartz grains, which are, to some extent, preserved. Recrystallized grains are not observed, flattened grains are scarce, and the most common deformational features are undulatory extinction and deformation lamellae. Iron oxides do not show evidence of recrystallization or other features of intracrystalline deformation. TEM studies and/or the determination of crystallographic preferred orientation as well as disorientation patterns of iron oxide grains would be the best way to address how the deformation was accommodated by these phases, which is beyond the scope of this article.
Holyoke \& Tullis, 2006). As rock strength has to be analyzed at constant mineral strength ratio (Handy, 1990), any reaction, during deformation generating new mineral phases may imply drastic changes in deformation processes. Consequently, one can argue that owing to the reducing reaction in our experiments, the PSC in BIF samples varies during deformation. The production of magnetite was identi- fied in all samples. Different thicknesses of reaction rims around samples from hydrostatic experiments (Table 1, Figure $3 \mathrm{~A})$ characterize the reduction reaction's dependency on time. Indeed the presence of magnetite grains randomly distributed only in deformed samples suggests that deformation processes enhance the reaction (Figure 3D). However, Siemes et al. (2003) showed that the strength of mag- 

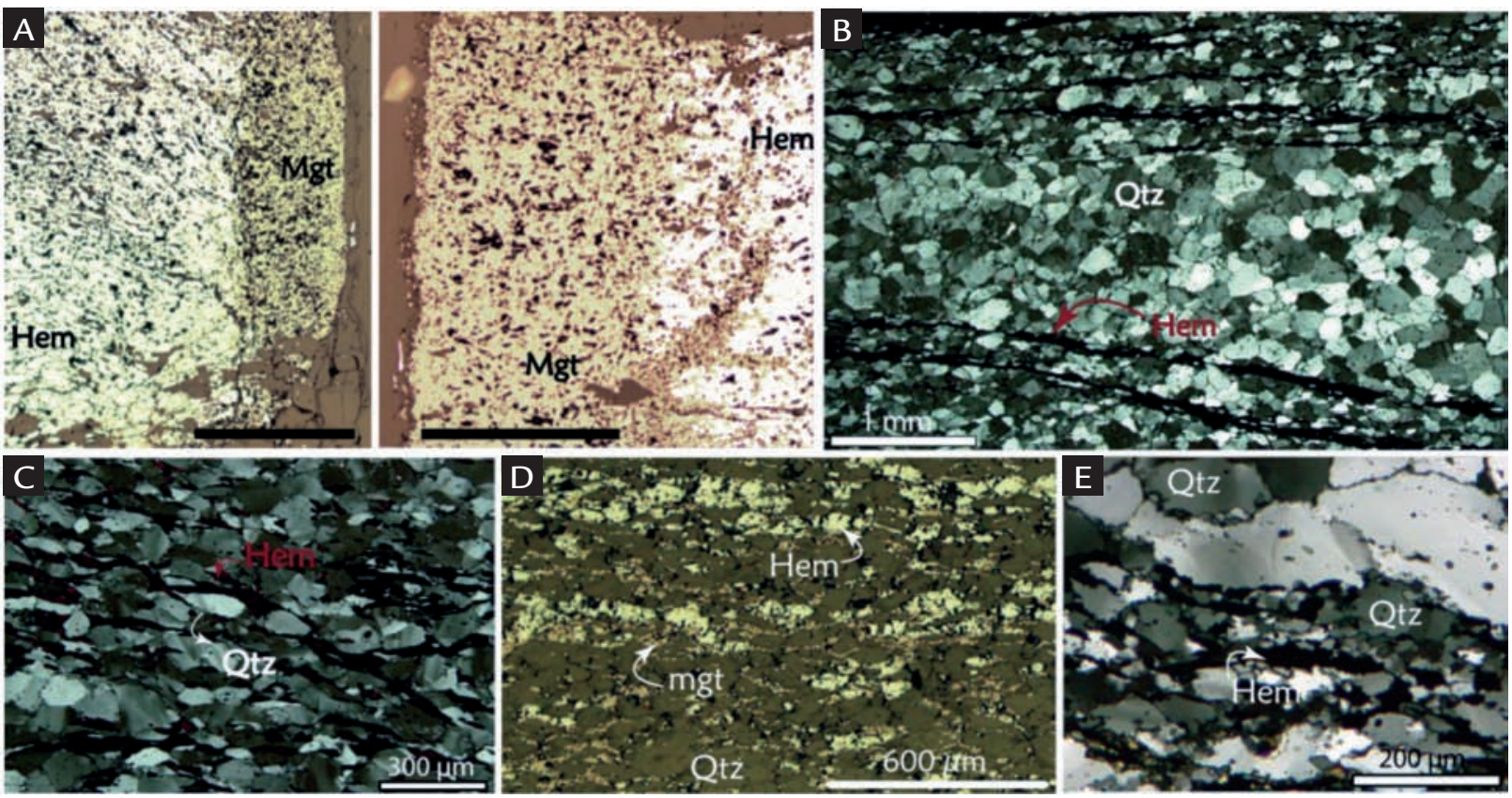

Figure 3

Photomicrographs. A) Samples hydrostatically annealed showing reaction rims composed solely by magnetite grains (Mgt). On the left, the sample was kept under experimental condition for 10 hours; on the right, for 75 hours (length of black bars: $500 \mu \mathrm{m}$ ). B) Quartz (Qtz) rich layer from Type 1 sample (W1533) with well-defined compositional banding showing few grains with undulatory extinction and deformation lamellae (Hem: hematite). C) Flattened quartz (Qtz) grains, showing undulatory extinction and deformation lamellae when surrounded by hematite (Hem) grains into hematite rich layers (W1533, same sample as b). D) Magnetite (mgt) grains parallel to the foliation, within a hematite (Hem) rich domain (Qtz: quartz). E) Quartz (Qtz) grains showing sutured boundaries and recrystallized grains at the contact with hematite (Hem) plates; sample deformed at $10^{-6} \mathrm{~s}^{-1}$. (photomicrographs $a$ and $d$ were taken using reflected plane polarized light, while for $b, c$ and $e$ transmitted cross-polarized light was used).

netite might be neglected if compared to the strength of hematite. Therefore, the experimental deformation of BIF samples do represent a good way to understand the rheology of quartz rich aggregates in the presence of weaker phase (iron oxide: either hematite or magnetite), showing a considerable PSC as observed comparing the curves in the Figure 2. The similar strength between BIF samples and those presented by Siemes et al. (2003) suggests that the confining pressure has no strong effect on these samples, with the caveat that the confining pressure used by Siemes et al. (2003) was much lower than in the present experiments.

The strength of pure quartz aggregate compared to the strength of BIF under the adopted experimental conditions shows that BIF samples are considerably weaker than quartzite with only $~ 10-15$ $\%$ of iron oxides. The experimentally deformed BIF samples have shown strength lower than $325 \mathrm{MPa}$, and turned out to be as weak as pure hematite aggregates. While the variation in the strength of pure hematite aggregate is related only to change in the strain rate (Figure $2 \mathrm{~B}$, considering the same temperature), the compositional banding appears to be a key factor for the strength of the BIF samples.
Samples W1565 and W1530 have the same iron oxide content (Table 1) but present different strengths at a strain rate of $10^{-5} \mathrm{~s}^{-1}$. The observed strength contrast between 270-325 MPa (W1533) to 90 $\mathrm{MPa}$ (W1530), at $10^{-5} \mathrm{~s}^{-1}$, is therefore not related to a difference in iron oxide content, but possibly due to the indistinct compositional banding in the latter sample. As iron oxides are weaker than quartz, such rheological patterns suggest that, at faster strain rate the strength of BIF with well-developed compositional banding depends, mainly, on the strength of the stronger phase, which is quartz. Such mechanical behavior is defined by Handy (1990) as load-bearing framework.

In contrast, the increase in iron oxide content allows the interconnection of iron oxide layers (Figure 3C and E) that apparently makes BIF samples as weak as pure hematite aggregates, even in the presence of $\sim 75 \%$ of quartz (W1530). In this case, the bulk rheology is controlled by the weaker phase (iron oxides) and it can be described as a matrix-controlled rheology (Handy, 1990, Holyoke \& Tullis, 2006).

At $10^{-6} \mathrm{~s}^{-1}$, the presence of the pure quartz bands does not appear to affect the bulk rheology. This suggests one of two possibilities: (1) owing to differences in the strain rate dependence of quartz and hematite/magnetite, the quartz strength becomes more similar to oxide strength at lower strain rates, or (2) the strength of the iron oxides controls the bulk rheology in both samples, forming interconnected layers of weak phase throughout the sample (type 2 sample) or localized in the microlayered domains that accommodate most of the strain (Figure 1A).

The fact that the strength of the more homogeneous type 2 samples deformed at $10^{-5} \mathrm{~s}^{-1}$ is quite variable (compare W1565 and W1530 in Figure 2A) and that W1565 was deformed by a strain rate stepping experiment (deformed at $10^{-5} \mathrm{~s}^{-1}$ after a long interval of deformation at $10^{-6} \mathrm{~s}^{-1}$ ) thus allowing more time for reaction suggests that the influence of the reduction of hematite to magnetite on the rheology of the samples must be considered. Nevertheless further experiments are still required to determine to what extent the reduction from hematite to magnetite may influence the rheology of BIF.

Distinct microstructural patterns of quartz grains in load-bearing framework and matrix-controlled rheology attest the strain partitioning and strain localization into the iron oxide rich domains, for type 1 sample, or into interconnected layers of 
iron oxides (matrix), for type 2 sample. Samples with load-bearing framework rheology show pure quartz bands as the least strained regions; with no evidence of microstructures that indicate intracrystalline deformation even at axial strain up to $40 \%$. Flattened and recrystallized quartz grains appear solely in the domains with fine iron oxide micro-layering, characterizing local boudin-matrix controlled rheology (Handy, 1990) and indicating that, although the strength of the weak phase prevails, grains of the stronger phase are not passive and also accommodate strain. In contrast, preserved quartz grains in samples with matrix-controlled rheology, characterize clast-matrix behavior (Handy, 1990), where strain appears to be accommodated almost exclusively by the weak phase.

One could argue that only quartz grains surrounded by iron oxide grains are strained due to the initial differences in grain size. It is well established that grains with platy shape pin the growth of other mineral phases (Passchier \& Trouw, 2005). The pinning process is well characterized in quartzites with mica, in which quartz

\section{Conclusions}

Our experiments show that:

- The strength of banded iron formations is dependent on iron oxide content, fabric anisotropy and strain rate; progressive strain enhances reducing reaction, characterized by the development of magnetite. Even with quartz content up to $85-90 \%$, BIF can be as weak as pure hematite aggregates, depending on strain rate and on how the iron oxide grains are distributed in the aggregate.

- At a strain rate of $10^{-5} \mathrm{~s}^{-1}$, the strength of samples with strong fabric an-

\section{Acknowledgements}

The authors would like to thank the anonymous reviewer for the suggestions and comments and Prof. Hanna Jordt Evangelista for the editorial handling. The financial support by CNPq, Conselho Nacional de Desenvolvimento Científico e Tecnológico - Brasil, grain size in mica-rich domains is smaller than in quartz-rich portions (Masuda et al., 1991, Shea \& Kronenberg, 1993 Song \& Ree, 2007). In analogy to mica, specular hematite also pins quartz grains and the smaller quartz grains at the contact with iron oxide rich layers would be expected to localize deformation, while larger grains in pure quartz bands would be preserved. Nevertheless Tullis et al. (1990) have experimentally shown that in either case, with or without grain size variation, quartz aggregates deform homogenously and strain localization is not observed. Strain weakening in quartz aggregates is actually related to the presence of recrystallized grains, which are free of intracrystalline defects, have lower strength and better accommodate strain (Hirth \& Tullis, 1992, Chernak et al., 2009). Consequently, the strain localization observed in BIF samples must occur due to PSC between quartz and iron oxides, mainly hematite.

The differential stress versus axial strain plots (Figure 2) obtained from the present experiments and the observed microstructural features of the BIF samples show the dependency of the rock strength on iron oxide content, fabric anisotropy and strain rate. The occurrence of a welldeveloped compositional banding or of interconnected iron oxide layers, that is related to iron oxide content, leads to the transition between a load-bearing framework with local boudin-matrix controlled rheology to a clast-matrix controlled rheology (Handy, 1990). Such transitions may be responsible for the weakening observed during deformation of samples W1533 and W1556 (Figure 2A). In contrast, the clastmatrix controlled rheology characterizes a steady-state flow with constant flow stress (Figure 2A, W1530). At slower strain rate the matrix-controlled rheology takes over and no variation in strength is observed between sample with well developed compositional banding and homogenously distributed iron oxide. This can be explained by the variation of PSC, as temperature and strain rate have strong effect on the strength of minerals and on the creep processes (e.g. Handy, 1990, Siemes et al., 2003, Chernak \& Hirth, 2010) and can drastically affect the bulk rheology. isotropy depends, primarily, on the strength of quartz and the bulk rheology is framework supported. Locally boudin-matrix controlled rheology is recognized owing to domains with fine iron oxide layering.

- Local matrix-controlled rheology implies strain partitioning into hematite rich layers, inducing strain localization and consequent strain weakening.

- Increase in iron oxide content and transition from load-bearing to matrix controlled rheology, decreases sample strengths.

- Deformation of the same materials at the slower strain rate of $10^{-6} \mathrm{~s}^{-1}$ has the same effect as increasing the iron oxide content with the decrease of the sample strength.

- At slower strain rate the matrixcontrolled rheology takes over and the strength of BIF is not dependent on fabric anisotropy or on iron oxide content. The banded sample becomes as weak as pure and homogeneous hematite aggregates.

\section{References}

BRACE, W. F., KOHLSTEDT, D.L. Limits on lithospheric stress imposed by laboratory experiments. J. of Geophys. Res., v. 84, p. 6248-52, 1980.

BÜRGMANN, R., DRESEN, G. Rheology of the Lower Crust and Upper Mantle: Evidence from Rock Mechanics, Geodesy, and Field Observations. Annu. Rev. Earth Planet. Sci., v. 36, p. 531-567, 2008. 
BUROV, E. B., WATTS, A. B. The long-term strength of continental lithosphere: "jelly sandwich" or "crème brûlée"? GSA Today, v. 12, p. 4-10, 2006.

BRUDY, M., ZOBACK, M. D., FUCHS, K., RUMMEL, F., BAUMGÄRTNER, J. Estimation of the complete stress tensor to $8 \mathrm{~km}$ depth in the KTB scientific drill holes: implications for crustal strength. J. Geophys. Res., v. 102, p. 18453-76, 1997.

CHERNAK, L., HIRTH, G., SELVERSTONE, J., TULLIS, J. Effect of aqueous and carbonic fluids on the dislocation creep strength of quartz. J. of Geophys. Res., v.114, B04201, 2009. 18p.

CHERNAK, L., HIRTH, G. Deformation of antigorite serpentinite at high temperature and pressure. Earth and Planetary Science Letters, v. 296, p. 23-33, 2010.

DE RONDE, A. A., HEILBRONNER, R., STÜNITZ, H., TULLIS, J. Spatial correlation of deformation and mineral reaction in experimentally deformed plagioclase-olivine aggregates. Tectonophysics, v. 389, p.93-109, 2004.

DE RONDE, A. A., STÜNITZ, R., TULLIS, J., HEILBRONNER, H. Reaction-induced weakening of plagioclase-olivine composites. Tectonophysics, v. 409, p. 85-106, 2005.

DELL'ANGELO, L. N., TULLIS, J. Fabric development in experimentally sheared quartzites. Tectonophysics, v. 169, p. 1-21, 1989.

GLEASON, G. C., TULLIS, J. Improving flow laws and piezometers for quartz and feldspar aggregates. Geophysical Research Letters, v. 20, n.19, p. 2111-2114, 1993.

GOETZE, C., EVANS, B. Stress and temperature in the bending lithosphere as constrained by experimental rock mechanics. Geophys. J. R. Astron. Soc., v. 59, p. 463-478, 1979.

HANDY, M. R. The Solid-State Flow of Polymineralic Rocks. J. of Geophys. Res., v.95, n. B6, p. 8647-8661, 1990.

HANSEN, L. N., ZIMMERMAN, M. E., KOHLSTEDT, D. L. Grain boundary sliding in San Carlos olivine: Flow law parameters and crystallographic-preferred orientation. J. of Geophys. Res., v. 116, B08201, 2011. 16 p.

HIRTH, G., TULLIS, J. Dislocation creep regimes in quartz aggregates. Journal of Structural Geology, v. 14, p. 145-159, 1992.

HIRTH, G., KOHLSTEDT, D. L. Experimental constraints on the dynamics of the partially molten upper mantle: Deformation in the diffusion creep regime. J. of Geophys. Res., v. 100, p. 1981-2001, 1995a.

HIRTH, G., KOHLSTEDT, D. L. Experimental constraints on the dynamics of the partially molten upper mantle 2 . Deformation in the dislocation creep regime. J. of Geophys. Res., v. 100, p. 15441-15449, 1995b.

HIRTH, G., KOHLSTEDT, D. L. Rheology of the upper mantle and the mantle wedge: a view from the experimentalists. In: EILER, J. (ed.) Inside the Subduction Factory. Geophys. Monogr, 138. Washington, DC: Am. Geophys. Soc., p. 83-105, 2003.

HIRTH, G., TEYSSIER, C., DUNLAP, W. J. An evaluation of quartzite flow laws based on comparisons between experimentally and naturally deformed rocks. Int. Journal Earth Science, v. 90, p. 77-87, 2001.

JACKSON, J. Strength of the continental lithosphere: time to abandon the jelly sandwich? GSA Today, v. 12, p. 4-9, 2002.

HOLYOKE, C. W., TULLIS, J. Mechanisms of weak phase interconnection and the effects of phase strength contrast on fabric development. Journal of Structural Geology, v. 28, p. 621-640, 2006.

HOLYOKE, C. W., KRONENBERG, A. K. Accurate differential stress measurement using the molten salt cell and solid salt assemblies in the Griggs apparatus with applications to strength, piezometers and rheology. Tectonophysics, v. 494, p. 17-31, 2010.

KARATO, S.-I., PATERSON, M.S., FITZGERALD, J.D. Rheology of synthetic olivine aggregates: influence of grain size and water.J. of Geophys. Res., v. 91, p. 8151-8176, 1986.

KRONENBERG, A. K., TULLIS, J. Flow strengths of quartz aggregates: Grain size and pressure effects due to hydrolytic weakening.J. of Geophys. Res., v. 89, p.4281-4297, 1984.

MAINPRICE, D. H., PATERSON, M. S. Experimental studies of the role of water in the plasticity of quartzites. J. of Geophys. Res., v. 89, p. 4257-4269, 1984.

MASUDA, T., KOIKE, T., YUKO, T., MORIKAWA, T. Discontinuous grain growth of quartz in metacherts: the influence of mica on a microstructural transition. Journal of Metamorphic Geology, v. 9, p. 389-402, 1991.

MEI, S., KOHLSTEDT, D. L. Influence of water on plastic deformation of olivine aggregates 1. Diffusion creep regime. J. of Geophys. Res., v. 105, p. 21457-21469, 2000a.

MEI. S., KOHLSTEDT, D. L. Influence of water on plastic deformation of olivine aggregates 2. Dislocation creep regime. J. of Geophys. Res., v. 105, p. 21471-21481, 2000 b. 
PASSCHIER, C. W., TROUW, R. A. J. Microtectonics. (2. Ed.). Springer Berling, 2005. 289 p. POST, A., TULLIS, J. The rate of water penetration in experimentally deformed quartzite: implications for hydrolytic weakening. Tectonophysics, v. 295, p. 117-137, 1998.

POST, A., TULLIS J. A recrystallized grain size piezometer for experimentally deformed feldspar aggregates. Tectonophysics, v. 303, p. 159-173, 1999.

ROSIÈRE, C. A., SIEMES, H., QUADE, H., BROKMEIER, H. G., JANSEN, E. M. Microstructure, texture and deformation mechanism in hematite. J. Struct. Geol., v.23, p.1429-1440, 2001.

ROSIERE, C. A., SPIER, C. A., RIOS, F. J., SUCKAU, V. E. The Itabirites of the Quadrilatero Ferrifero and Related High-Grade Iron Ore Deposits: An Overview. In: HAGEMANN, S., ROSIÈRE, C.A., GUTZMER, J., BEUKES, N. (eds.) Banded Iron Formation-Related High-Grade Iron Ore. Reviews in Economic Geology, v. 15, p. 223-254, 2008.

RUTTER, E. H., BRODIE, K., H. Experimental grain size-sensitive flow of hot-pressed Brazilian quartz aggregates. Journal of Structural Geology, v. 26, p. 2011-2023, 2004a.

RUTTER, E. H., BRODIE, K., H. Experimental intracrystalline plastic flow in hotpressed synthetic quartzite prepared from Brazilian quartz crystals. Journal of Structural Geology, v. 26, p. 259-270, 2004b.

SHEA, W. T., KRONENBERG, A. K. Strength and anisotropy of foliated rocks with varied mica contents. Journal of Structural Geology, v. 9, n. 10, p. 1097-1121, 1993.

SIEMES, H., KLINGENBERG, B., RYBACKI, E., NAUMANN, M., WOLFGANG, S. W., JANSEN, E., ROSIÈRE, C. A. Texture, microstructure, and strength of hematite ores experimentally deformed in the temperature range $600-1100^{\circ} \mathrm{C}$ and at strain rates between $10^{-4}$ and $10^{-6} \mathrm{~s}^{-1}$. Journal of Structural Geology, v. 25, p. 1371-1391, 2003.

SIEMES H., KLINGENBERG B., RYBACKI E., NAUMANN M., SCHAFER W., JANSEN E. KUNZE K. Glide systems of hematite single crystals in deformation experiments. Ore Geology Reviews, v. 33, p. 255-279, 2008.

SIEMES, H., RYBACKI, E., KUNZE K., KLINGENBERG, B., NAUMANN, M., BROKMELER, H-G., JANSEN E. Development of microstructure and texture of hematite ores deformed to large strain in torsion: can texture identify the prevailing strength and creep mechanisms during deformation? Advanced Engineering Materials, v. 12, n. 10, p. 1003-1007, 2010.

SONG, W. J., REE, J-H. Effect of mica on the grain size of dynamically recrystallized quartz in a quartzemuscovite mylonite. Journal of Structural Geology, v. 29, p.1872-1881, 2007.

STIPP, M., TULLIS, J., BEHRENS, H. The effect of water, temperature and strain rate on the dislocation creep microstructure, recystallized grain size and flow stress of quartz. TSK 11 Göttingen, 3p., 2006.

STÜNITZ H., FITZGERALD J. Deformation of granitoids at low metamorphic grade: 2. Granular flow in albite-rich mylonites. Tectonophysics, v. 221, p. 299-324, 1993.

STUNITZ, H., TULLIS, J. Weakening and strain localization produced by syndeformational reaction of plagioclase. Int. J. Earth Sciences, v. 90, p. 136-148, 2001.

STÜNITZ, H., FITZ GERALD, J.D., TULLIS, J. Dislocation generation, slip systems, and dynamic recrystal. in experimentally deformed plagioclase single crystals. Tectonophysics, v. 372, p. 215-233, 2003.

TUlLIS, J., CHRISTIE, J. M., GRIGGS, D. T. Microstructure and preferred orientations of experimentally deformed quartzites. Bulletin of the Geological Society of America, v. 84, p. 297-314, 1973.

TULLIS, J., TULLIS, T. Experimental rock deformation techniques. In: HOBBS, B. E., HEARD, H. C. (eds) Mineral and Rock Deformation; Laboratory Studies; The Paterson Volume, American Geophysical Union, Washington, DC, p. 297324, 1986.

TULLIS, J., DELL'ANGELO, L. N., YUND, R. A. Ductile shear zones from brittle precursors in feldspathic rocks: the possible role of dynamic recrystallization. In: DUBA A., DURHAM, W., HANDIN, J., WANG, H. (eds,) The Brittle-Ductile Transition, Amer Geophys Union Geophys Monograph 56, Washington, DC, USA, 67-82, 1990.

TWISS, R. J. Theory and applicability of a recrystallized grain size paleopiezometer. Pure Appl. Geophys, v. 115, p. 227-244, 1977. 